dodnes nemalé rozpaky, stejně jako bouřlivé transformační dění v devadesátých letech a na počátku 21. století, kdy docházelo k četným organizačním proměnám.

Po úvodu následuje hlavní část knihy - 16 rozhovorů se 17 osobnostmi (v jednom př́ípadě se jedná o rozhovor se dvěma osobami naráz), ${ }^{4}$ které jsou řazeny podle jednotlivých fakult. Ke každému rozhovoru je připojen stručný životopisný medailon a fotografie narátora. Kniha obsahuje jmenný rejstř́k a anglické a české resumé.

Rozhovory s osobnostmi prrinášejí sice subjektivní pohled na dějiny této specifické vysokoškolské instituce, ale zároveň také podávají osobitá svědectví, díky nimž si čtenář může udělat představu o činnosti, vztazích a poměrech na pracovištích fakult AMU v různých obdobích. Kniha je také vhodným doplňkem k syntetizujícím dějinám AMU. ${ }^{5}$

Michal Továrek

doi: $10.14712 / 23365730.2021 .27$

\title{
Marta Edith Holečková, Př́běh zapomenuté univerzity. Univerzita 17. listopadu (1961-1974) a její místo v československém vzdělávacím systému a společnosti
}

Filozofická fakulta Univerzity Karlovy, Praha 2019, 202 s., ISBN 978-80-7308-921-4

Recenzovaná kniha se zabývá dějinami Univerzity 17. listopadu. Text knihy vychází z doplněné a mírně upravené disertační práce, kterou autorka ${ }^{1}$ obhájila v roce 2018 , a zabývá se tématem, které v dosavadní literatuře nebylo komplexně zpracováno.

V úvodu autorka popisuje volbu svého tématu a jeho vymezení. Nechybí zde ani zachycení současného obrazu Univerzity 17 . listopadu ve vzpomínkách pamětníků. Úvodní část uzavírá přehled pramenů a literatury.

První část knihy se nazývá Komunistické Československo a třetí svět a přináší popis zásadních momentů československé zahraniční politiky ve vztazích k zemím třetího světa. Zachycuje také Československo a Prahu v mezinárodních souvislostech. Československo bylo v poválečném období většinou evropských zemí vnímáno jako země blahobytu a vyspělého hospodářství. Leželo sice na okraji sovětského bloku, ale uprostřed Evropy,

4 Dana Stříbrná (nar. 25. 8. 1938), sekretářka Centra pohybové př́ípravy, sportu a rehabilitace AMU; Jan Císař (nar. 28. 1. 1932), dramaturg, kritik a pedagog, DAMU; Miloslav Klíma (nar. 22. 9. 1941), dramaturg a pedagog, DAMU; Nina Malíková (nar. 18. 10. 1945), pedagožka, DAMU a badatelka v oblasti loutkového divadla; Jan Vedral (nar. 20. 11. 1955), dramatik, dramaturg a pedagog, DAMU; Alena Zemančíková (nar. 18. 6. 1955), dramaturgyně, publicistka a autorka prozaických a dramatických děl, DAMU; Drahomíra Vihanová (nar. 31. 8. 1930), filmová režisérka a scénáristka, FAMU; Karel Vachek (nar. 4. 8. 1940), filmový režisér a pedagog, FAMU; Alois Fišárek (nar. 7. 1. 1943), stř̌ihač a pedagog, FAMU; Josef Hubka (nar. 18. 10. 1938), zvukový mistr, FAMU; Zdeněk Kopka (nar. 3. 6. 1932), filmový technik, FAMU; Lordan Zafranović (nar. 11. 2. 1944), filmový režisér, FAMU; Božena Brodská (nar. 27. 7. 1922), tanečnice, pedagožka a historička baletu, HAMU; Ivana Loudová (nar. 8. 3. 1941), hudební skladatelka, HAMU; Jiří Hlaváč (nar. 12. 10. 1948), klarinetista a saxofonista, HAMU; Eva Plochová (nar. 3. 2. 1955), sekretářka čtyř kateder HAMU; Jaromír Havlík (nar. 17. 5. 1950), hudební historik a teoretik, HAMU.

Martin Franc a kol., Dějiny Akademie múzických umění v Praze, Nakladatelství AMU, Praha 2017.

1 Marta Edith Holečková působí v Ústavu pro soudobé dějiny AV ČR, zabývá se samizdatem, metodou oral history a vysokými školami v ,socialistickém Československu“. 
a spojovalo tak nejen východ se západem, ale také se severní a západní Afrikou, Asií a Latinskou Amerikou. Poválečné Československo se proto stávalo útočištěm emigrantských komunit z nejrůznějších částí světa a také sídlem několika mezinárodních organizací (např. Mezinárodní svaz studentstva). Mezi výrazné emigrantské komunity, které se usadily na území Československa, patřili zejména uprchlíci z Řecka, Španělska a Jugoslávie, dalšími skupinami byli také např. levicoví idealisté z Velké Británie, USA, Nového Zélandu a Austrálie, menší skupinu tvořili Italové nebo Francouzi. Praha byla také vyhlášeným cílem latinskoamerických levicových exulantů (např. chilský básník Pablo Neruda).

Část Československá společnost a třetí svět zachycuje vnímání zemí třetího světa československou společností prostřednictvím cestopisné a reportážní literatury. Zde lze zmínit především Hanzelku a Zikmunda, jejichž zážitky se objevovaly v tisku a rozhlase, v padesátých a šedesátých letech byly také jejich cestopisy opakovaně vydávány knižně. Zprávy a filmy Hanzelky a Zikmunda o Africe měly za následek vznik určitého názorového stereotypu: „domorodé obyvatelstvo je ryzí, dobrosrdečné, nicméně naivně věřící různým bludům, běloši jsou bud' vykořist'ující kolonisté, nebo hodní cestovatelé a lékaři“. Dalším zdrojem informací byla např. kniha Probuzený světadíl novináře Stanislava Budína, v níž autor mj. definuje africký socialismus a podává výklad o pomoci socialistických zemí Africe. Dále lze jmenovat knihu Jindřicha Liona Od Limpopa k Vltavě, která přináší prrímou zkušenost afrických studentů v Praze. Zahraniční studenti se objevují také u filmových a televizních tvůrců, např. Jaromil Jireš a jeho Křik, Drahomíra Vihanová Fuga na černých klávesách nebo např. Vladimír Sís Jiný malý princ. Samostatnou kapitolou jsou filmy, které natočili studenti FAMU z cizích zemí, např. Zima v Československu cejlonského režiséra Piyasiri Gunaratny. Kromě cestopisů a filmů podporoval československý stát také vědecké bádání o zemích třetího světa. Pro potřeby československé zahraniční politiky vznikl v roce 1957 Ústav pro mezinárodní politiku a ekonomii (pozdější Ústav mezinárodních vztahů). Na pražské Filozofické fakultě UK vznikl v roce 1960 samostatný obor afrikanistika, v roce 1967 pak Středisko iberoamerikanistických studí. Prvním uceleným vědeckým dílem věnovaným Africe byla rozsáhlá dvojdílná publikace Dějiny Afriky vydaná pod vedením afrikanisty Ivana Hrbka v roce 1966.

Třetí část se zabývá hlavním tématem - Univerzitou 17. listopadu. Na přelomu 50. a 60. let přicházelo do Československa v důsledku postupující dekolonizace stále více cizích studentů a dosavadní zázemí jim již nepostačovalo. V Moskvě vznikla v roce 1961 vysoká škola pro cizince - Univerzita družby národů Patrice Lumumby, která sloužila jako přímá inspirace pro založení obdobné instituce v Praze. Na počátku 60. let studovalo v Československu celkem 1809 studentů ze sedmdesáti zemí světa. Většina z nich (1068) pocházela z evropských a asijských zemí, které patřily do „socialistického tábora“, 119 studentů bylo z řad řecké a španělské emigrace, dále 285 z Afriky, 240 z Asie, 56 z Latinské Ameriky.

Při založení vzdělávací instituce se vycházelo z přesvědčení, že absolvent získá kvalitní vzdělání, bude vhodně ideologicky proškolen a takto formován se vrátí do své vlasti, kde zaujme významné místo ve státní správě a díky svým kontaktům s Československem bude prostředníkem při diplomatických a obchodních jednáních. Většina studentů byla vybrána svými vládami na základě stipendií nabídnutých Československem prostřednictvím ministerstva zahraničních věcí a našich zastupitelských úřadů.

Univerzita měla vzdělávat cizince $\mathrm{v}$ oborech, které neexistovaly na žádné další vysoké škole v Československu. Předpokládalo se, že půjde o výchovu a vzdělání budoucích 
učitelů. Univerzita měla dále zajištovat výuku češtiny jako cizího jazyka a připravovat cizí studenty ke studiu na našich vysokých školách. Dále zde měly být shromažd’ovány informace o politické a kulturní problematice jednotlivých států pro školy, kde cizinci studují, a pro vyslání československých expertů do těchto zemí.

Univerzita 17. listopadu měla zpočátku tři fakulty: Fakultu jazykové a odborné prŕípravy, Fakultu společenských věd a Fakultu prrírodovědeckou a technickou (v roce 1966 byla tato fakulta zrušena). V čele stál rektor, který měl k dispozici kolegium rektora a tři prorektory, $\mathrm{v}$ čele jednotlivých fakult pak stál děkan, který měl k dispozici dva proděkany. Dále zde byla vědecká rada a kolegium děkana. Základní jednotky představovaly katedry. V čele rektorátu stál kvestor. Rektorovi přímo podléhala účelová zařízení, především knihovna a dokumentační středisko. Důležitou součástí Univerzity 17. listopadu bylo také studijní oddělení, v roce 1966 transformované do Ústavu pro organizaci a metodiku studia zahraničních studentů, který do roku 1971 spadal pod Fakultu společenských věd. Univerzita fungovala $\mathrm{v}$ prostorách na dnešním Senovážném náměstí a ve školicích střediscích po celé republice.

Fakulta jazykové a odborné př́ípravy zajišt'ovala roční jazykový př́pravný kurz, kde si měli studenti osvojit český nebo slovenský jazyk na takové úrovni, aby dokázali pokračovat ve studiu na některé ze zdejších vysokých škol. Př́pravný jazykový kurz probíhal ve třech trimestrech a byl zakončen zkouškou.

Fakulta společenských věd umožňovala dosáhnout úplného vysokoškolského studia nejen v češtině, ale také v angličtině nebo francouzštině. Studium bylo čtyřleté, první dva roky zahrnovaly studium společného společenskovědního základu (např. historie, filozofie), následně se volila specializace: mezinárodní vztahy politické, mezinárodní vztahy ekonomické, národohospodářské plánování, teorie a plánování výchovy, sociologie, kulturní politika, veřejná správa nebo družstevnictví.

Při Fakultě společenských věd bylo pro československé studenty zahájeno od 1. záŕí 1963 studium překladatelství a tlumočnictví. Kromě těchto studentů docházela na Univerzitu ještě další, početnější skupina, a to československých absolventů, kteří se připravovali na povolání experta. Univerzita umožňovala také postgraduální studium a doplňující vysokoškolské kurzy.

Většinu pedagogů tvořili externisté z jiných vysokých škol, z Československé akademie věd, vědeckých ústavů a dalších institucí. Mezi kmenovými zaměstnanci se vedle spolehlivých kádrů objevovali i ti s pochybným kádrovým profilem, protože se Univerzita neobešla bez jejich odborných znalostí, což se týká specialistů na tlumočení a překlad, z nichž lze jmenovat např. romanistu Josefa Forbelského nebo překladatele $\mathrm{z}$ francouzštiny a ruštiny Josefa Václava Bečku.

Od počátku existence provázely projekt této vysoké školy pochybnosti o její efektivnosti, které nakonec převážily, a tak byla v roce 1974 Univerzita 17. listopadu zrušena. Za příčinu jejího neúspěchu lze považovat několik faktorů - zájem o země třetího světa postupně opadal, projekt vzdělávání zahraničních studentů nenaplňoval očekávání, absolventi se totiž do svých domovů nevraceli, studenti byli často také ideologicky nespolehliví. Činnost školy byla také ochromena čistkami po roce 1968 - celkem z Univerzity odešlo 46 pracovníků.

Závěrečná část knihy, nazvaná Zahraniční studenti, se věnuje národnostnímu složení cizinců, kteří byli rozděleni do několika kategorií podle zemí jejich původu: studující z kapitalistických států, ze zemí socialistického tábora a z rozvojových zemí; posledně 
jmenovaná kategorie se dělila ještě do několika podskupin (dle přednostního zájmu Alžírsko, Guinea, Mali a Ghana, Severní Vietnam, Mongolsko, Severní Korea a Kuba). Ve skupině studentů ze zemí třetího světa tvořili většinu studenti z arabských zemí (např. Sýrie, Libanon), z Afriky převažovali studenti z bývalých britských a francouzských kolonií (Súdán, Ghana, Keňa, Mali) a Etiopie, více než polovinu studujících z Latinské Ameriky tvořili Kubánci, ostatní pocházeli převážně z Bolívie, Brazílie, Mexika a Venezuely, následovala Indonésie, Indie, Afghánistán a také Vietnam. Prostor je zde věnován také sociálním záležitostem - životu na kolejích, společenskému a veřejnému životu a konfliktům. ${ }^{2}$ Knihu zakončuje závěr, přehled pramenů a literatury, jmenný rejstř́k a cizojazyčné resumé.

Autorka ve své práci přinesla komplexní pohled na dosud nezpracovanou problematiku. Práce je cenným př́íspěvkem $\mathrm{k}$ dějinám instituce, která přes krátkou dobu existence zanechala v československém vysokoškolském prostředí výraznou stopu. Kniha je vhodná pro badatele v oblasti univerzitních dějin, v problematice migrace cizinců nebo studentské každodennosti.

Michal Továrek

doi: $10.14712 / 23365730.2021 .28$

\section{Radomil Hradil, 17. listopad ' 89 - co se stalo na Národní Franesa, Lelekovice 2019, 268 s., ISBN 978-80-907414-4-7}

Recenzovaná publikace zemědělského inženýra a překladatele Radomila Hradila přináší osobitý pohled na události spjaté se 17. listopadem 1989.

Úvodní kapitola „Prefix: Brno, listopad 1989“ popisuje dění, které následovalo po událostech na Národní tř́́dě. Dne 20. listopadu v 17:00 došlo (za účasti autora) k protirežimní demonstraci na náměstí Svobody v Brně. Na základě svědeckých výpovědí se zde dozvídáme o okolnostech demonstrace a jejích aktérech. Náměstí bylo zprvu obklopeno kordony bezpečnostních složek, které legitimovaly každého, kdo vejde. Pod tlakem davů byly však kordony rozpuštěny. Nakonec se zde dle slov (možná až př́liš nadsazených) jednoho z účastníků sešlo asi 80000 lidí. Na improvizovaném pódiu vystoupili brněnští herci František Derfler a Břetislav Rychlík. Za svoláním demonstrace stála brněnská disidentka Hana Holcnerová, jež působila jako „brněnská odnož“ Východoevropské informační agentury Petra Uhla, který s ní konzultoval zveřejnění zprávy o údajně mrtvém studentovi Martinu Šmídovi. Holcnerová se rozhodla sepsat pozvánku na demonstraci za tohoto studenta. V Brně poté pokračovala série demonstrací až do generální stávky konané dne 27. 11.

Kapitola „Praha, listopad 1989: Př́ípravy“ nás na základě výpovědí účastníků uvádí k organizačním počátkům manifestace, které vznikly v univerzitním prostředí z potřeby založit studentské hnutí nezávislé na tehdejším Svazu socialistické mládeže (SSM). Z tohoto prostředí vzešlo hnutí STUHA. První velkou akcí měla být manifestace 17. listopadu. Mezitím se ukázalo, že oslavy chystalo i hnutí Studentské tiskové a informační středisko (STIS) zaštítěné SSM. Nakonec došlo k ohlášení manifestace na 16:00 na Albertově.

2 K této problematice srov. v tomto časopise také Daniela Hannová, Problémovi elegáni. Arabští studenti v Praze v 50. a 60. letech 20. století, AUC-HUCP 54/2, 2014, s. 105-125. 